Article

\title{
Genetically Modified Heat Shock Protein90s and Polyamine Oxidases in Arabidopsis Reveal Their Interaction under Heat Stress Affecting Polyamine Acetylation, Oxidation and Homeostasis of Reactive Oxygen Species
}

\author{
Imene Toumi ${ }^{1, *}$, Marianthi G. Pagoulatou ${ }^{1}\left(\mathbb{D}\right.$, Theoni Margaritopoulou ${ }^{2,+} \oplus$, Dimitra Milioni ${ }^{2}$ \\ and Kalliopi A. Roubelakis-Angelakis ${ }^{1, *}$ \\ 1 Department of Biology, University of Crete, Voutes University Campus, 70013 Heraklion, Greece \\ 2 Department of Plant Biotechnology, Agricultural University of Athens, Iera odos 75, 11855 Athens, Greece \\ * Correspondence: imtoumdem@gmail.com (I.T.); poproube@uoc.gr (K.A.R.-A.) \\ + Present Address: Benaki Phytopathological Institute, Department of Phytopathology, Laboratory of \\ Mycology, St. Delta 8, 14561 Kifissia, Greece.
}

Received: 22 June 2019; Accepted: 12 August 2019; Published: 3 September 2019

\begin{abstract}
The chaperones, heat shock proteins (HSPs), stabilize proteins to minimize proteotoxic stress, especially during heat stress (HS) and polyamine (PA) oxidases (PAOs) participate in the modulation of the cellular homeostasis of PAs and reactive oxygen species (ROS). An interesting interaction of HSP90s and PAOs was revealed in Arabidopsis thaliana by using the PLFY:HSP9ORNA $i$ line against the four AtHSP90 genes encoding cytosolic proteins, the T-DNA Athsp90-1 and Athsp90-4 insertional mutants, the Atpao3 mutant and pharmacological inhibitors of HSP90s and PAOs. Silencing of all cytosolic HSP90 genes resulted in several-fold higher levels of soluble spermidine (S-Spd), acetylated Spd ( $\mathrm{N}^{8}$-acetyl-Spd) and acetylated spermine $\left(\mathrm{N}^{1}\right.$-acetyl-Spm) in the transgenic Arabidopsis thaliana leaves. Heat shock induced increase of soluble-PAs (S-PAs) and soluble hydrolyzed-PAs (SH-PAs), especially of SH-Spm, and more importantly of acetylated Spd and Spm. The silencing of HSP90 genes or pharmacological inhibition of the HSP90 proteins by the specific inhibitor radicicol, under HS stimulatory conditions, resulted in a further increase of PA titers, $\mathrm{N}^{8}$-acetyl-Spd and $\mathrm{N}^{1}$-acetyl-Spm, and also stimulated the expression of PAO genes. The increased PA titers and PAO enzymatic activity resulted in a profound increase of PAO-derived hydrogen peroxide $\left(\mathrm{H}_{2} \mathrm{O}_{2}\right)$ levels, which was terminated by the addition of the PAO-specific inhibitor guazatine. Interestingly, the loss-of-function Atpao3 mutant exhibited increased mRNA levels of selected AtHSP90 genes. Taken together, the results herein reveal a novel function of HSP90 and suggest that HSP90s and PAOs cross-talk to orchestrate PA acetylation, oxidation, and $\mathrm{PA} / \mathrm{H}_{2} \mathrm{O}_{2}$ homeostasis.
\end{abstract}

Keywords: heat shock proteins; heat stress; polyamines; polyamine oxidases; PA acetylation; PA oxidation; PA back-conversion; hydrogen peroxide

\section{Introduction}

Heat stress impairs plant growth and productivity globally [1]. Plants, as sessile organisms, are highly adaptive to harsh environmental conditions and accommodate the developmental programming in a wide temperature range. Survival above optimal temperature conditions is accompanied by a massive accumulation of HSPs [2-4]. HSPs maintain and stabilize proteins and transcription factors through heterocomplex formation and folding/unfolding, thus controlling the activation/inhibition 
of their complex associates [5-8]. Furthermore, HSPs bind to targeted molecules through specific receptors for translocation to non-peptide target molecules, such as hormones $[9,10]$, and they act in all cellular compartments [11].

In Arabidopsis thaliana, the HSP90 gene family consists of seven members [12-16]. Four highly homologous HSP90 genes (AtHSP90-1, -2, -3 and -4) encode cytosolic proteins, suggesting important functional redundancies [17,18]. They associate with key components of essential cellular processes [19] and play crucial role(s) in areas as diverse as cellular homeostasis, cell growth, development, and organismal evolution [5,20-22]. Recent evidence has highlighted the commitment of HSP90 proteins on plant defense mechanisms [23], brassinosteroid or auxin signaling pathways [10,24,25], and stomata patterning [26]. Moreover, HSP90s are essential for the vegetative-to-reproductive phase transition and flower development [22].

The inhibition of HSP90 increases the stochastic variation inherent to developmental processes by releasing morphogenic traits controlled by the HSP90 buffering capacity of mutations. Administration of radicicol (specific HSP90 inhibitor) to wild type (WT) plants reduces viability under physiological conditions [5], whereas many homozygous hsp90 mutant lines are lethal [15,27]. In Arabidopsis, the Athsp90c-1 mutant exhibits a high rate of albinos and aborted seeds, confirming that the HSP90 protein localized specifically to chloroplasts is essential for viability [27]. HSP90s interact with tetrapyrroles, by modulating the photosynthesis-associated nuclear genes ( $P h A N G$ ) expression, in response to oxidative stress [28]. They associate with the suppressor of the G2 allele of skp1 (SGT1) for the stabilization of the nucleotide-binding domain and leucine-rich repeat-containing (NLR) immune sensors, which mediate plant defense mechanisms [29]. In addition, HSP90s participate in stress signaling pathways [18,30-33]. In fact, under stress, the inhibition of HSP90 induces, in most cases, deregulation of the putative client's functionality and alteration of cell processes [31,34].

Polyamines are highly reactive aliphatic polycations [35]. The more abundant and best studied PAs are the diamine putrescine (Put), the triamine Spd and the tetramine Spm. Polyamine homeostasis is determined by a complex regulatory mechanism which includes turnover, export/transport, as well as modifications of their amino-groups, via mechanisms such as acetylation and conjugation [36-39]. Polyamines, per se or via their metabolic products such as $\mathrm{H}_{2} \mathrm{O}_{2}$, interfere with a plethora of dynamic metabolic and developmental processes [40-42], as well as stress responses [37,38,43-47]. Also, PAs are highly involved in adaptative mechanisms of hyperthermophilic proteins [48], whereas they interfere with HSP synthesis under increasing temperatures by an unknown mechanism [49].

Polyamine oxidases participate in the regulation of PA homeostasis, mediating their oxidation/ back-conversion [39,50]. In Arabidopsis thaliana, oxidation/back-conversion of PAs is mediated by the peroxisomal AtPAO2 (At2g43020), AtPAO3 (At3g59050), AtPAO4 (At1g65840) and the cytosolic AtPAO1 (At5g13700) and AtPAO5 (At4g29720) [46]. Products of PAO-mediated enzymatic action include aldehydes and $\mathrm{H}_{2} \mathrm{O}_{2}$ [43,47]. Recently, PAOs were confirmed to play an important role in the control of cell proliferation (in animals) through the generated toxic aldehydes and $\mathrm{H}_{2} \mathrm{O}_{2}$ and were proposed as fine competitors for antiproliferative therapies [51]. In plants, the generated $\mathrm{H}_{2} \mathrm{O}_{2}$, depending on its "signature", can signal either the orchestration of tolerance to abiotic/biotic stresses or execution of programmed cell death (PCD) [37-39,52-60]. Furthermore, an NADPH-oxidase/PAO feedback loop controls oxidative burst under salinity in tobacco [61]. In animals [62], but not in plants [47,63], acetylated PAs are the major form of the conjugated PAs and the favorite substrate for PAOs.

Evidence for the interplay between HSPs and PAs was first provided for the HSP70 family. Depletion of PAs in a cell line derived from rat hepatoma induces direct inhibition of HSP70 expression [64]. In addition, exogenous Spm increases the transcription of HSP9O and subsequently enhances heat tolerance in Arabidopsis thaliana [65]. Furthermore, the underexpression of PAO results in thermotolerant tobacco plants [66]. Such findings suggest the existence of an evolutionary conserved network which acts for co-regulation of PAs and HSPs to efficiently orchestrate HS response. However, the exact mechanism remains elusive. In this work, we attempted to identify potential links between HSP90 and PA homeostasis implicating more specifically $P A O$ genes, $\mathrm{PAO}$ activity and $\mathrm{H}_{2} \mathrm{O}_{2}$ levels. 
Impaired HSP90 action, derived either from the HSP90RNAi effect or from pharmacological inhibition of the HSP90 protein activity, induced increase in PA titers, especially of the acetylated-PAs, $\mathrm{N}^{8}$-acetyl-Spd and $\mathrm{N}^{1}$-acetyl-Spm and the conjugated forms. The interconnection between HSP90 and PAs was further determined since loss of PA homeostasis by impairing a major path of PA oxidation had a specific impact on HSP9O both at transcriptional and translational levels. Similarly, genetic modification of HSP90 had a profound effect on genes involved in the PA oxidation pathway. Our results reveal a novel interaction by which $H S P 90 \mathrm{~s} / \mathrm{PAO}$ s co-regulate the intracellular titers of $\mathrm{PAs} / \mathrm{H}_{2} \mathrm{O}_{2}$ with an unknown yet impact on stress response.

\section{Results}

\subsection{Underexpression of AtHSP90 1-4 Genes Results in Higher S-PAs and $S-N^{8} / N^{1}$ Acetylated PA Titers}

Polyamine homeostasis and PAO expression/PAO activity are cell/tissue/organ- specific, strongly affected by the ontogenetic stage of the plant/organ and the growing conditions [40,41]. In order to identify any potential link between HSP90 and PA homeostasis, the endogenous PA titers were analyzed in the leaves of 15 day-old WT, Athsp90-1 and Athsp90-4 mutants and pLFY:HSP90RNAi transgenic plants. More specifically, the titers of soluble Put (S-Put), S-Spd, S-Spm, and the two mono-acetylated PAs, $\mathrm{N}^{8}$-acetyl-Spd and $\mathrm{N}^{1}$-acetyl-Spm were determined (Figure $1 \mathrm{~A}$ ). The leaves of Athsp90 1-4 contained significantly higher levels of S-Spm and acetyl-PAs and the $p L F Y: H S P 90 R N A i$ line contained higher levels of S-Put, S-Spd and S-Spm compared to WT. Interestingly, the pLFY:HSP90RNAi transgenics exhibited a nearly 18 -fold increase of $\left(\mathrm{N}^{8}\right.$-acetyl-Spd $+\mathrm{N}^{1}$-acetyl-Spm) compared to the WT (Figure 1A).

To further confirm that genetic inhibition of the HSP90 genes affects PA homeostasis independently of plant age, PA contents were determined in 35 day-old mutants/transgenics and WT plants. Consistently, although a general decrease in PA levels was observed compared to the 15 day-old seedlings, in accordance with our previous results for tobacco and grapevine [40], all three lines, Athsp90 1-4, and pLFY:HSP90RNAi contained significantly greater S-Spm with the highest levels recorded in the $P L F Y: H S P 90 R N A i$ line, which also contained higher S-Put (Figure 1B). The most striking effect of AtHSP90 deregulation on PA titers was, as in the 15 day-old plants, the significant increase of $\mathrm{S}$-acetylated forms of Spd ( $\mathrm{N}^{8}$-acetyl-Spd) and Spm ( $\mathrm{N}^{1}$-acetyl-Spm) in the Athsp90 transgenic lines (Figure 1B). The picture was somehow different in the conjugated SH-fraction (Figure S1). The Athsp90 1-4 lines contained significantly higher SH-Put, SH-Spd and SH-Spm, as well as SH-acetyl-PAs, when compared to the corresponding titers in the S-fraction whereas the PLFY:HSP90RNAi line contained significantly lower amounts of SH- and acetyl-PAs, when compared to the Athsp90 1-4 mutants and to WT (Figure S1). The results point strongly to a complex mechanism connecting HSP90 and PA homeostasis which may be ontogenetically regulated. 


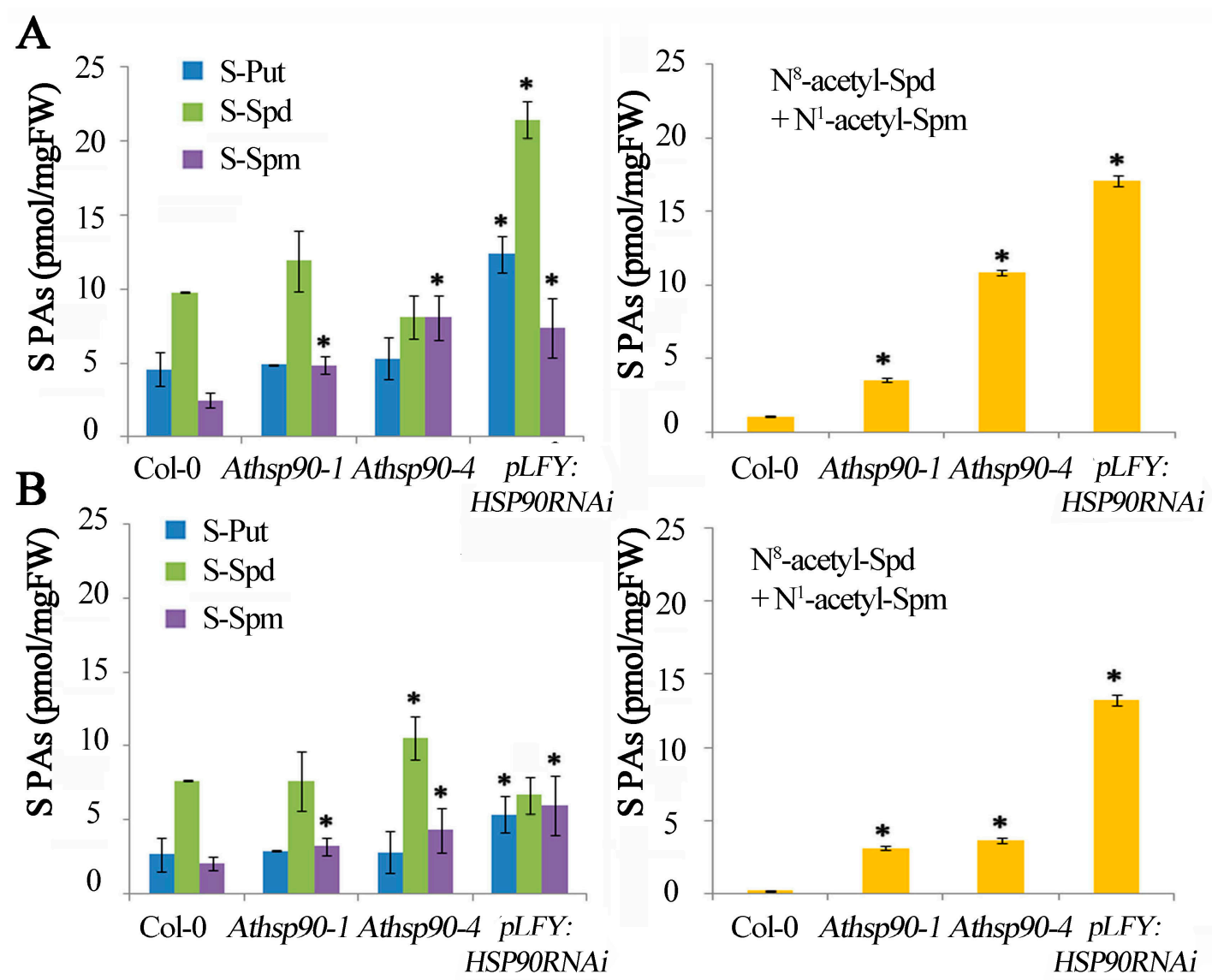

Figure 1. Endogenous polyamine titers in WT, Athsp90-1, Athsp90-4 and pLFY:HSP90RNAi mutants of Arabidopsis thaliana. (A) Soluble Putrescine, Spermidine and Spermine (S-Put, S-Spd, S-Spm) and Soluble acetylated $\left(\mathrm{N}^{8}\right.$-acetyl-Spd $+\mathrm{N}^{1}$-acetyl-Spm) polyamine contents in leaves of 15 day-old seedlings. (B) Soluble (S-Put, S-Spd, S-Spm) and soluble acetylated ( $\mathrm{N}^{8}$-acetyl-Spd $+\mathrm{N}^{1}$-acetyl-Spm) polyamine contents in leaves of 35 day-old WT, Athsp90-1, Athsp90-4 and pLFY:HSP90RNAi plants. Values from 8 replicates from two independent experiments were pooled for statistical analysis. Asterisks indicate statistically significant differences from WT control $(p<0.05)$.

2.2. The Increased PAs in the Athsp90 Mutants Correlate with Increased $\mathrm{H}_{2} \mathrm{O}_{2}$ Content. HSP90s Modulate Free Radical Production

Under normal conditions, PA back-conversion catalyzed by PAOs leads to $\mathrm{H}_{2} \mathrm{O}_{2}$ production balancing the intracellular oxygen consumption rate [38]. In order to examine whether HSP90s modulate $\mathrm{H}_{2} \mathrm{O}_{2}$ production, the in situ semi-quantitative method based on staining with 3,3'-diaminobenzidine (DAB) was employed. We found that all 15 day-old Athsp90 and pLFY:HSP90RNAi seedlings had increased $\mathrm{H}_{2} \mathrm{O}_{2}$ content compared to WT seedlings, as assessed by DAB staining (Figure 2). Hydrogen peroxide levels paralleled the increased S-PAs titers, which are substrates of PAOs; the $p L F Y: H S P 90 R N A i$ line as well as the Athsp90-1 and the Athsp90-4 young seedlings, which contained the highest S- and acetyl-PAs, exhibited the highest $\mathrm{H}_{2} \mathrm{O}_{2}$ levels compared to WT (Figures $1 \mathrm{~A}$ and 2). These results further point to a certain correlation between HSP90s, PAs, and PAO-generated $\mathrm{H}_{2} \mathrm{O}_{2}$. 


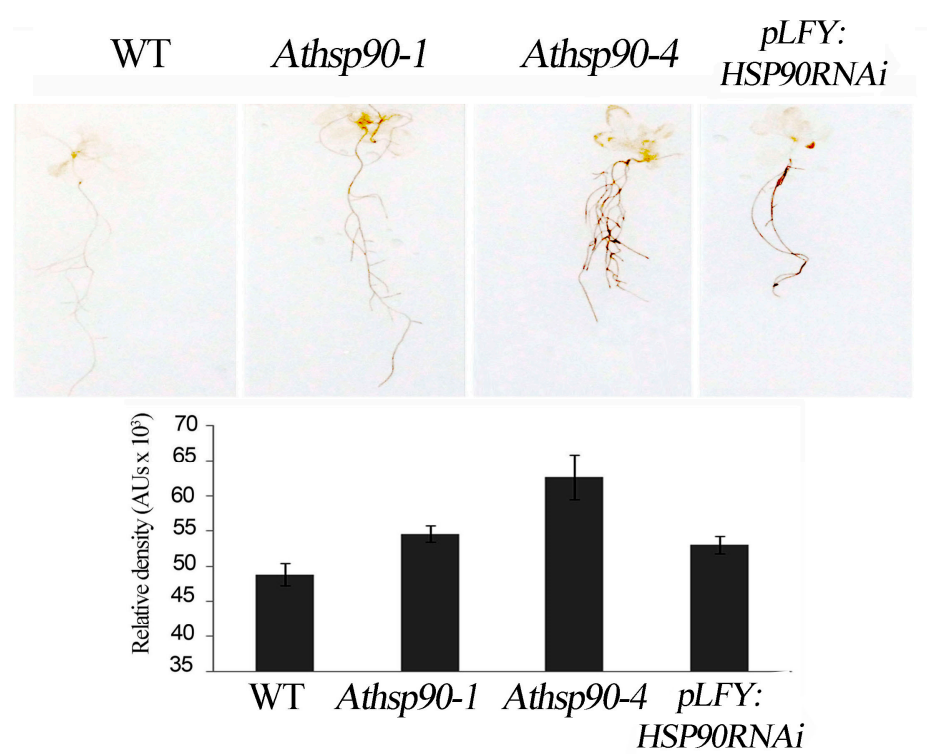

Figure 2. In situ DAB detection of hydrogen peroxide in WT, Athsp90-1, Athsp90-4 and pLFY:HSP90RNAi seedlings of Arabidopsis thaliana grown on Murashige and Skoog (MS) plates and relative pixels density of leaf staining. Values from 8 replicates from two independent experiments were pooled for statistical analysis.

2.3. Under HS, Genetic Depletion and Pharmacological Inhibition of HSP90 Affect PA Homeostasis and Enhance Acetylated Forms

Since HS induces transcription of the HSP90 genes [12,13,16], it was of interest to assess whether genetic depletion of HSP90 1-4 genes by RNAi [22] or pharmacological inhibition of HSP90 in WT Arabidopsis plants would similarly affect PA homeostasis under HS conditions. Thus, analysis of PA titers was performed in leaves of WT and pLFY:HSP90RNA $i$ transgenic plants following acute HS ( $1 \mathrm{~h}$ at $42{ }^{\circ} \mathrm{C}$ ) in the presence (in WT) or absence (in pLFY:HSP9ORNAi) of radicicol (Rad), a specific inhibitor of HSP90 activity. In WT, HS resulted in increased S-Spm, and considerable decrease of SH-Spd and SH-Spm levels (Figure 3). Soluble-Spm is a common thermo-responsive indicator and has been proposed as a marker of thermotolerance [65]. The combined effect of HS + Rad resulted in increased S-Put, S-Spd, SH-Put, SH-Spd and SH-Spm when compared to HS treatment alone. In the WT, the $\mathrm{S}-\mathrm{N}^{8}$-acetyl-Spd and $\mathrm{N}^{1}$-acetyl-Spm titers were slightly affected by HS, whereas the inhibition of HSP90 by Rad resulted in significant increase of the $\mathrm{N}$-acetyl-PAs in both fractions $\mathrm{S}$ and SH (Figure 3). Similarly, genetic depletion of cytosolic HSP90s in the $p L F Y: H S P 90 R N A i$ line resulted in a significant increase of all S-PAs, SH-PAs as well as of S-acetyl-PAs and SH-acetyl-PAs under HS. In particular, S-Spd in PLFY:HSP90RNAi showed a nearly 3-fold increase (Figure 3). These data indicate that impairment of the HSP90 molecular chaperones, when coupled to the stimulatory effect of the HS-related pathway, increases further the deregulation of PA homeostasis and leads to a significant increase of acetylated PAs. 


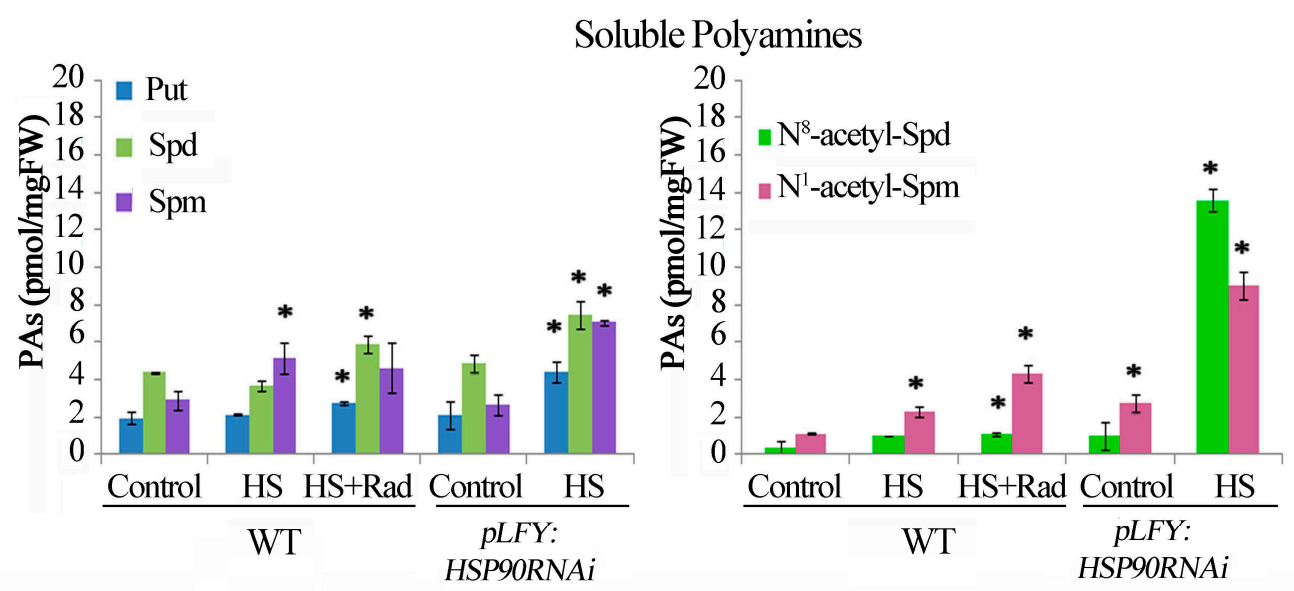

Soluble Hydrolyzed Polyamines
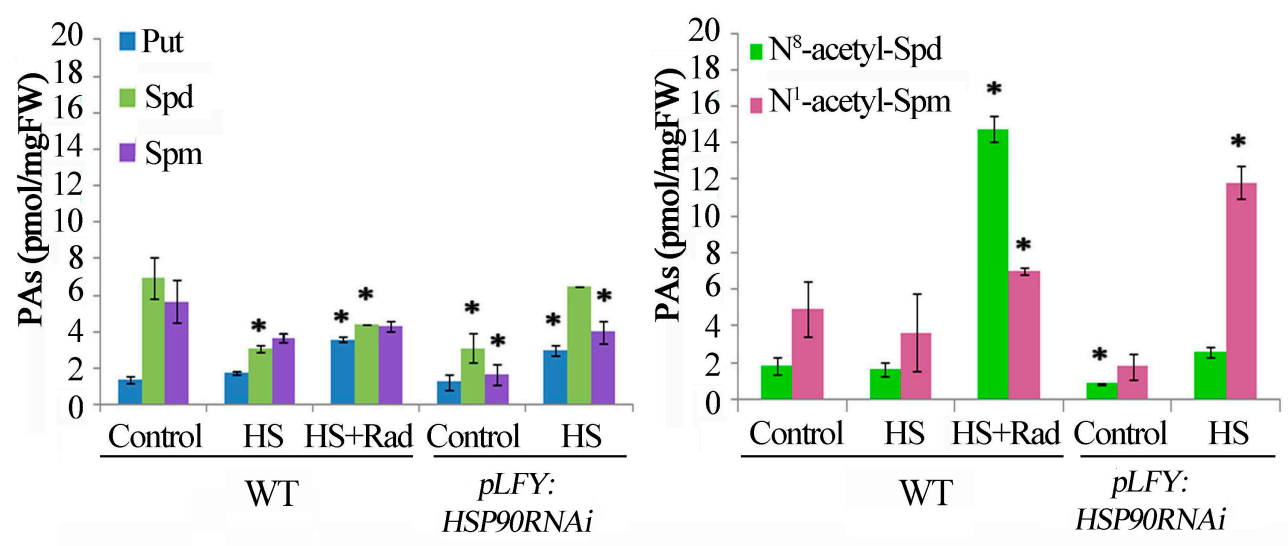

Figure 3. HSP90 activation/inhibition affects polyamine homeostasis in Arabidopsis thaliana. Endogenous Soluble (Put, Spd, Spm); Soluble acetylated ( $\mathrm{N}^{8}$-acetyl-Spd and $\mathrm{N}^{1}$-acetyl-Spm); Soluble hydrolyzed (Put, Spd, Spm); and Soluble hydrolyzed acetylated ( $\mathrm{N}^{8}$-acetyl-Spd and $\mathrm{N}^{1}$-acetyl-Spm) polyamine contents following HSP90 activation/inhibition in treated leaves. Leaves of WT and PLFY:HSP90RNAi transgenic plants followed brief HS $\left(1 \mathrm{~h}\right.$ at $42{ }^{\circ} \mathrm{C}$ ) in the presence (in WT) or absence (in $\left.p L F Y: H S P 90 R N A i\right)$ of radicicol (Rad). Values from 8 replicates from two independent experiments were pooled for statistical analysis. Asterisks indicate statistically significant differences from the WT control $(p<0.05)$.

\subsection{Genetic and Pharmacological Inhibitions of HSP90 Affect the PA Oxidation Pathway}

Taking into consideration the changes in PA titers and the high levels of $\mathrm{H}_{2} \mathrm{O}_{2}$ in the RNAi pLFY:HSP9ORNAi line (Figures 1 and 2), we studied the expression profile of AtPAO1, 3, 5 and AtHSP90 1-4 genes in WT and this transgenic line. To explore the impact that HSP90 could have on PA homeostasis, we studied the expression of AtPAO1, AtPAO3 and AtPAO5 genes in $p L F Y: H S P 90 R N A i$ plants in which cytosolic HSP90 proteins are markedly depleted $[16,20]$. In WT plants, HS increased mRNA levels of AtHSP90-1 and AtHSP90-4; treatment with HS + Rad also induced high AtHSP90-1 and AtHSP90-4 transcript levels when compared to the controls. It is worth noticing that the abundance of AtHSP90-1 is slightly lower when HS coupled with Rad than HS alone (Figure 4A).

AtPAO mRNAs in the PLFY:HSP90RNAi lines were increased when compared to WT under control conditions, which was not remarkably different under HS (Figure 4B). If the expression of $P A O$ genes was affected by HSP90 function, then Rad should modulate gene transcription pattern similarly to genetically compromised HSP90 activity. In fact, Rad application on WT plants induced the expression of the AtPAO1, AtPAO3 and AtPAO5 genes (Figure 4B). Consequently, pharmacological HSP90 inactivation affected the expression of PAO genes in a similar way to HSP90 mRNA depletion by RNAi silencing. Similar results were obtained when the abundance of PAO3 protein was assessed. 
The levels of PAO3 protein correlated well with the corresponding mRNA levels in both the WT and the PLFY:HSP90RNAi plants under the different treatments (Figure 4C).

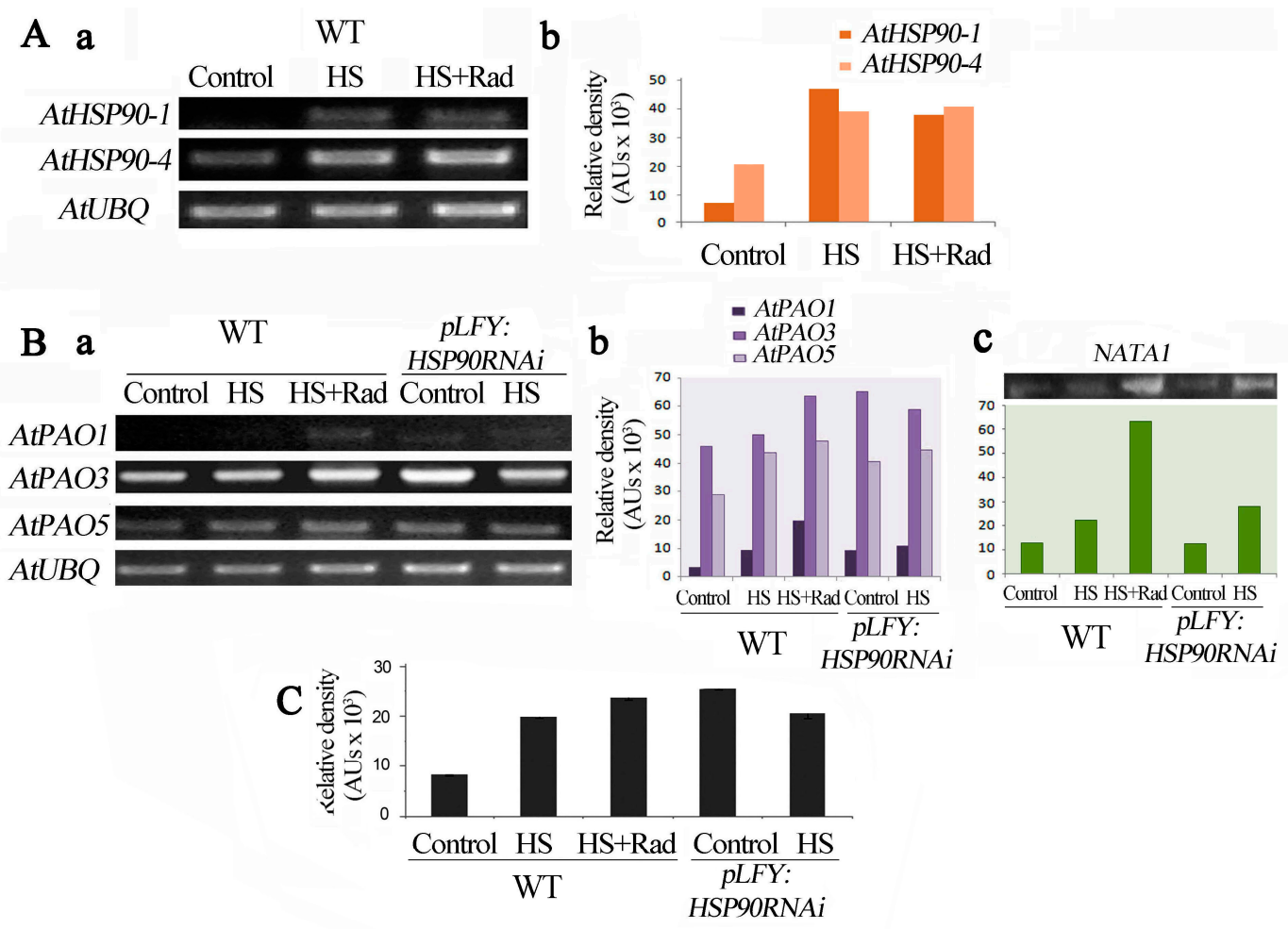

Figure 4. Inhibition of HSP90 affects levels of mRNAs of AtPAO1, AtPAO3, AtPAO5 and NATA1 genes, and PAO3 protein in Arabidopsis thaliana. (A) a. Abundance of transcripts of AtHSP90-1 and AtHSP90-4 genes in WT, b. relative pixels density of gel bands' intensities following normalization with AtUBQ. (B) a. Abundance of transcripts of AtPAO1, AtPAO3 and AtPAO5, b. relative pixels density of gel bands' intensities following normalization with AtUBQ, c. NATA1 mRNA levels in WT and PLFY:HSP90RNAi mutant, with relative densitometric measurements following normalization with AtUBQ. (C) PAO3 immunoreactive protein relative levels in the leaves under control, HS and HS + Rad conditions. Image software was used for numeric determination and quantification of gels bands' intensities.

\subsection{Inhibition of HSP90 under HS Induces Expression of NATA1, a Putative Acetyltransferase-Like Gene}

As shown above, leaves of $p L F Y: H S P 90 R N A i$ plants exposed to HS as well as leaves of WT exposed to HS coupled with Rad, exhibit a noticeable increase of acetylated forms of higher PAs (Figure 3). The Arabidopsis NATA genes are the closest homologues of mammalian PA acetyltransferases. Thus, due to the lack of identified genes regulating the acetylation of Spd and Spm in Arabidopsis, we prompted to examine the transcript levels of NATA1 gene (At2g39030) which is identified as a Put and ornithine acetyltransferase $[67,68]$, as a means to assess the genetic trend of PA acetylation under our conditions. Again, and by using excised leaves incubated in Morpholino Ethane Sulfonic acid (MES) and exposed to HS with (WT)/without Rad (Athsp90s), the WT and the PLFY:HSP90RNAi mutant under control conditions contained low amounts of NATA1 mRNA. Heat shock induced NATA1 expression in the WT and PLFY:HSP90RNAi plants, exhibiting a 2-fold increase of the transcript levels. Interestingly, in WT plants NATA1 transcripts increased more than 5-fold under HS in the presence of Rad. The results show that inhibition of HSP90 by the HSP inhibitor Rad releases PA acetylation process and suggest that PA acetylation is in fact inhibited by HSP90 (Figure 4B,C).

\subsection{PAO-Induced Stimulation during HSP90 Inhibition Is Responsible for the Increased $\mathrm{H}_{2} \mathrm{O}_{2}$}

Since inhibition of HSP90 induced PAO transcription and increased PAO protein levels (Figure 4B,C), supporting cross-talk between the inhibition of HSP90 and the stimulation of the PAO 
pathway, we were prompted to further establish this relationship; thus, PAO activity was determined, as $\mathrm{H}_{2} \mathrm{O}_{2}$ production, in leaves of WT plants treated with HSP90 inhibitor and in PLFY:HSP90RNAi, under HS. The results confirmed the activation of PAO under such conditions (Figure 5A and Figure S2A). To further test this finding, we also determined PAO activity in planta intact WT leaves infiltrated with Rad or Spd (as a positive control) and submitted to HS (Figure 5B). In addition, the results were confirmed by determining the endogenous $\mathrm{H}_{2} \mathrm{O}_{2}$ of leaves treated as above, which confirmed that in fact high PAO activity correlates with high $\mathrm{H}_{2} \mathrm{O}_{2}$ levels (Figure 5C). Finally, the increased amounts of $\mathrm{H}_{2} \mathrm{O}_{2}$ were further verified by in situ staining of WT leaves under HS and HS + Rad. Consistently, guazatine (specific PAO inhibitor), when administered simultaneously with Rad, reduced $\mathrm{H}_{2} \mathrm{O}_{2}$ levels, supporting that the higher PAO activity contributes to $\mathrm{H}_{2} \mathrm{O}_{2}$ generation upon HSP90 inhibition (Figure 5D). As with WT, the use of guazatine along with $\mathrm{HS}$ attenuated PAO activity in PLFY:HSP90RNAi leaves (Figure S3A,B).

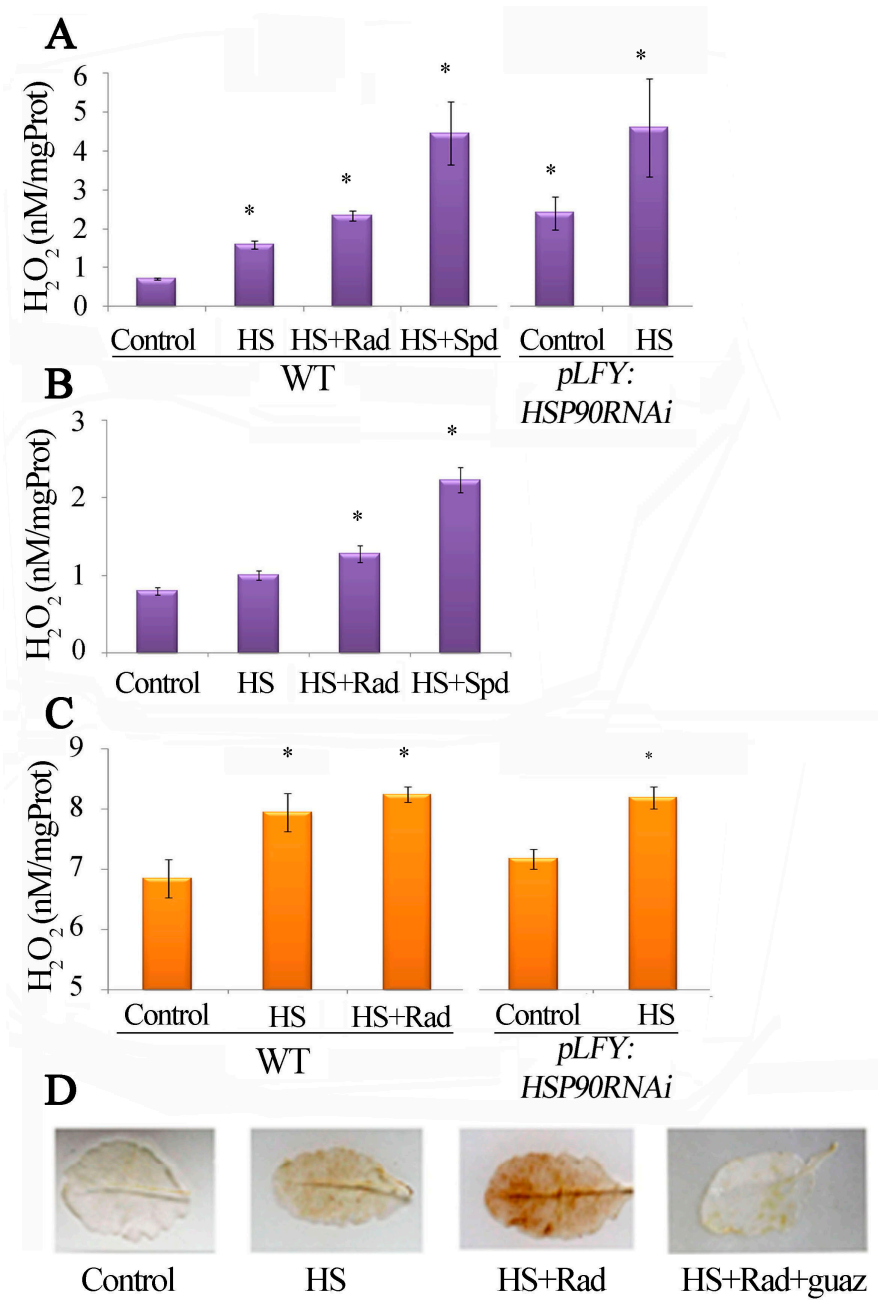

Figure 5. Inhibition of HSP90 stimulates the polyamine oxidation activity. Polyamine Oxidase (PAO) activity measured and evaluated through hydrogen peroxide production in: (A) Excised WT leaves cultured on MES medium and exposed to HS with/without Rad; and excised PLFY:HSP9ORNAi line leaves cultured on MES medium and exposed to HS. (B) In planta WT leaves infiltrated separately with water (control or HS); Rad, and Spd (as positive control) prior to exposure to HS. (C) Luminometric hydrogen peroxide quantification in WT leaves exposed to HS and HS + Rad, and PLFY:HSP9ORNAi mutant exposed to HS. (D) In situ DAB staining of hydrogen peroxide in WT control leaves treated with HS and HS + Rad and with HS + Rad + guazatine (Guaz). Values from 8 replicates from two independent experiments were pooled for statistical analysis. Asterisks indicate statistically significant differences from WT control $(p<0.05)$. 


\subsection{PAO and AtHSP90 Reciprocally Affect Each Other's Expression}

To examine whether PAO homeostasis has an impact on AtHSP90 expression, Atpao3 loss-of-function plants were tested. By applying HS to leaves incubated in MES medium, transcript analysis revealed that only AtHSP90-1 and AtHSP90-4 mRNAs were increased in the Atpao3 mutant compared to WT. The abundance of AtHSP90 1-4 mRNAs as well as HSP90 protein were analyzed in the Atpao3 mutant and the WT, under HS (Figure 6A,B). In the Atpao3, mRNA titers of the AtHSP90-1 and AtHSP90-4 were significantly greater compared to WT, whilst HS resulted in an obvious increase of the mRNA levels of the AtHSP90 1-4 genes (Figure 6A). Inhibition of HSP90 activity simultaneously to HS stimulation (HS + Rad) exerted no further significant effect on the AtHSP90 1-4 mRNA levels (Figure 6A).

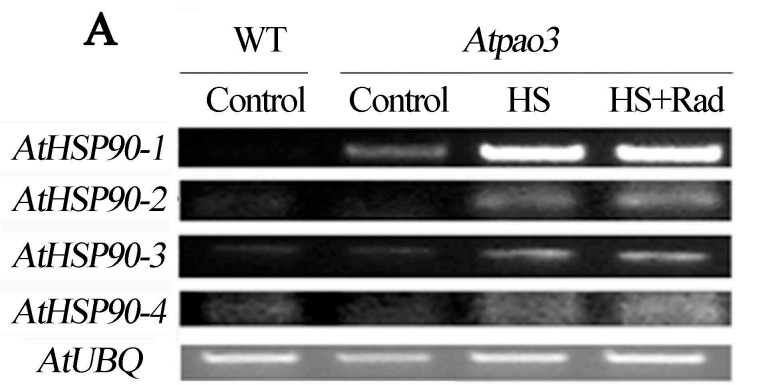

B
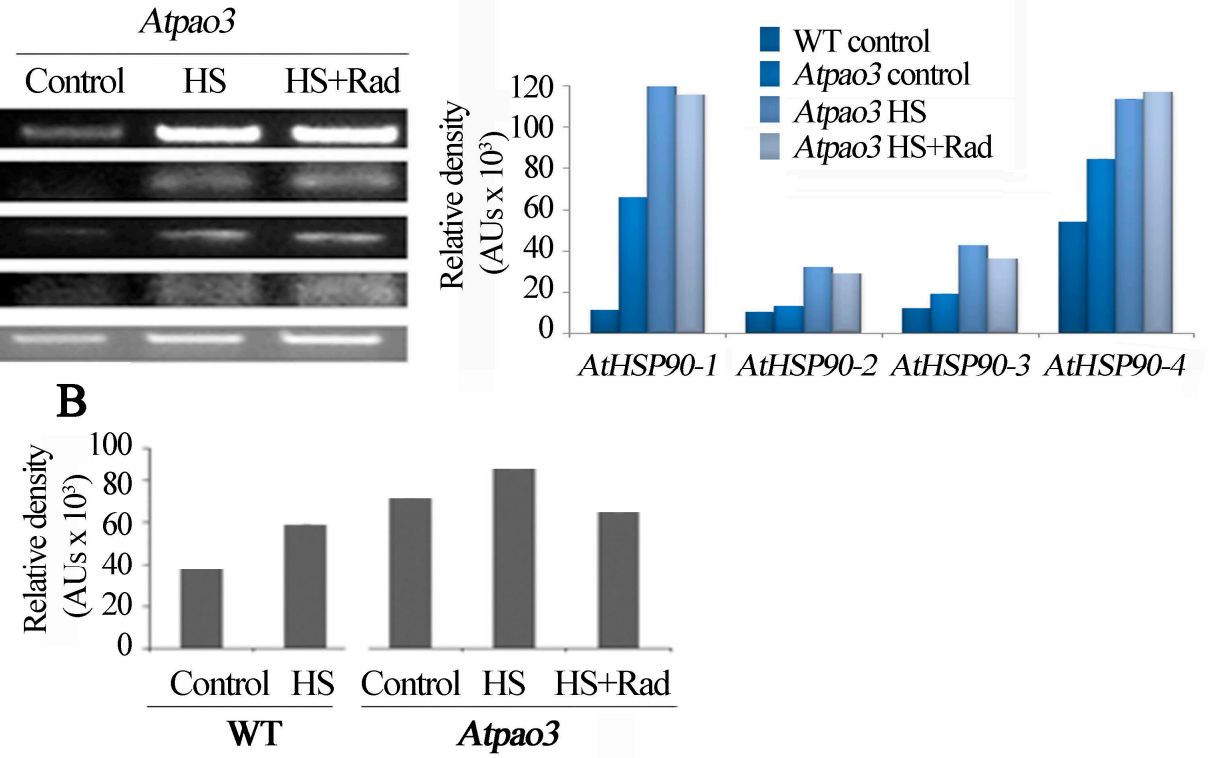

Figure 6. Abundance of cytosolic AtHSP90 mRNA in WT and Atpao3 mutant and HSP90 protein levels. Leaves were treated with HS and HS + Rad for $1 \mathrm{~h}$ at $42{ }^{\circ} \mathrm{C}$. (A) Reverse transcriptase (RT)-PCR of the four AtHSP90 cytosolic genes (AtHSP90 1-4) and relative intensities of bands normalized against ubiquitin. (B) Quantification of the HSP90 immunoreactive protein in control and HS- treated WT leaves, as well as in controls, HS and HS + Rad treated Atpao3 leaves.

It is known that HSP90 are essential molecular chaperones in eukaryotic cells, with key functions in signal transduction networks. To test whether HSP90 homeostasis is disrupted when the PA oxidation pathway is challenged, the molecular chaperone protein abundance was assessed. Immunoreactive HSP90 protein levels exhibited parallel increase under HS in both, WT and Atpao3 and was more abundant in the Atpao3 genotype (Figure 6B and Figure S2B). In pao3 mutant, the HSP90 protein levels were increased.

Furthermore, semi-quantitative reverse transcriptase (RT)-PCR revealed that the cytosolic AtHSP90 1-4 genes in Atpao3 seedlings (5, 10, and 15 day-old) revealed a general over-expression of these genes in the Atpao3 mutant compared to WT, at different time points (Figure S4).

Interestingly, the Atpao3 leaves contained lower endogenous mRNA levels of all four AtPAO genes (AtPAO1, 2, 4 and 5). Pharmacological inhibition of HSP90 activity under HS (HS + Rad) induced an increase in the AtPAO transcripts and restored the AtPAO mRNAs to levels similar to the WT control, except the AtPAO4 that remained low (Figure S5A). The restoration of the AtPAO mRNA levels in the Atpao3 mutant subsequently to the inhibitory effect of Rad on HSP90 activity suggests that AtPAOs are activated subsequently to HSP90 deregulation. Application of HS + Rad did not induce accumulation of acetyl-S-PAs in the Atpao3 mutant genotype (Figure S5B). 


\section{Discussion}

The hypothesis of cross-talk between HSPs and PAs was initially evoked through the finding that exogenous Spm increases mRNA levels of HSP90 and subsequently enhances heat tolerance in Arabidopsis [65]. Results herein support this hypothesis and reveal reciprocal molecular and biochemical interactions of HSP90/PAO genes and/or HSP90/PAO proteins. Depletion of cytoplasmic HSP90 results in increased levels of PAs and more specifically of $\mathrm{N}^{8}$-acetyl-Spd and $\mathrm{N}^{1}$-acetyl-Spm, which, under physiological conditions, are present only in traces in the leaves of WT (Figure 1) [69]. In animals, Spd/Spm acetyltransferase (SSAT) is a key enzyme participating in the first step of PA catabolism, mediating the acetylation of PAs whereas PAOs catalyze the final oxidation of acetyl-PAs. Overexpression of SSAT correlates with growth inhibition in a wide range of tumors [70-72]. Accumulation of acetyl-PAs by the increased activity of SSAT shifts the metabolism of PAs into lipids and carbohydrates through the increasing consumption of acetyl-CoA and ATP, leading to generation of ROS and, subsequently, to oxidative stress and proteotoxicity [71]. On the contrary, the acetyl-PAs are not the preferred substrates for PAOs in plants [39,55]. Acetylated-Put is directly linked to the pathogen-defense related signals [67] as well as the root cell de-differentiation process, probably as transient metabolite for GABA production [73]. The factors controlling the tri- and tetraamine (Spd and Spm) acetylation remain obscure. NATA1 is one of the few genes participating in the $\mathrm{N}$-acetylation of amine metabolism in Arabidopsis; ornithine is the favorite substrate when stimulated via methyl jasmonate [67] and Put as specific substrate when stimulated through jasmonate and salicylic acid [68], both involving the pathogen infection process. Analysis of the mRNA levels of the NATA1 in pLFY:HSP9ORNAi HS-treated leaves versus WT treated with HS +/- Rad confirms the stimulation of the NATA1 transcription under HS in both genotypes, and a further stimulation when HS is associated with HSP90 inhibitor in the WT (Figure 4B).

Both, HSP90s and PAs, are highly responsive to environmental challenges. HSP90s increase under stress, including heat, osmotic, and heavy metals, as well as biotic stress, whereas PAs exhibit complex profiles under such conditions [1,12,32,37,38,74-76]. Spermine plays a significant role in Arabidopsis thermotolerance, and exogenously applied Spm enhances HS response by inducing increase of mRNA levels of HSP genes [65]. Although sufficient information on the implication of HSP in proteotoxicity is lacking, it is well established that HSP chaperones are highly responsible for the prevention of protein degradation and misfolding and for preventing non-native proteins from non-specific intermolecular interactions, eliminating proteotoxicity propagation [77,78]. Nishizawa-Yokoi et al. [79] propose a model for HSP90s role in ROS-induced proteotoxic stress in Arabidopsis thaliana. They suggest that ROS accumulation results in inhibition of proteasome $26 \mathrm{~S}$, which induces a peculiar poly-ubiquitination. HSP90s, which act as Heat Shock Factor (HSF) repressors under normal conditions, release the HSF which regulates in turn the expression of a Heat Shock Transcription Factor A2 (HSFA2). Also, HSP90s regulate the production of superoxides mediated by NADPH-oxidase but are not required for the generation of $\mathrm{H}_{2} \mathrm{O}_{2}$ in human embryonic kidney cells [75]. Pharmacological inhibition of HSP90 in PC-12 cells induces cytotoxicity and cell death via oxidative stress by an unidentified mechanism [34]. Taking into consideration the involvement of HSP90 in cell proliferation processes, we can speculate that both, HSP90s and PAs may be integrated in a specific biochemical pathway through the competitive regulation of cell cytotoxicity and ROS generation involving potentially the homeostatic regulation of oxidation and/or acetylation of PAs.

The drastic reduction of HSP90s results in deregulation of PA titers and induction of the PAO pathway, which generates $\mathrm{H}_{2} \mathrm{O}_{2}$. In WT, the pharmacological inhibition of HSP90s under HS induces expression of AtPAO genes, suggesting that HSP90s may be implicated in a way to decelerate the action of PAOs into the cell. Indeed, the $P L F Y: H S P 90 R N A i$ line exhibits elevated endogenous AtPAO mRNA levels similar to those in WT when treated with HS + Rad, suggesting that biochemical inhibition of HSP90s defines a favorable endogenous potential of PA oxidation (Figures 4 and 5).

As key agents in the regulation of thermotolerance, HSP90s show strong connection with other stress-related factors in signal perception and transduction $[18,80]$. Within this context, HS induces 
in both WT and pLFY:HSP90RNAi mutant an increase of $\mathrm{H}_{2} \mathrm{O}_{2}$, which is a predictable trait of stress (Figure 5C). Simultaneous application of $\mathrm{HS}+$ Rad enhances $\mathrm{H}_{2} \mathrm{O}_{2}$ generation in WT. In parallel with the induction of PA oxidation, the use of guazatine, a specific inhibitor of PAO, attenuates the HS + Rad-dependent accumulation of $\mathrm{H}_{2} \mathrm{O}_{2}$, confirming the concomitant link between HSP90 inhibition/PA oxidation-back-conversion/ $\mathrm{H}_{2} \mathrm{O}_{2}$ generation. HSP90 inhibition results in AtPAOs expression and increased transcript levels, especially the AtPAO1 and AtPAO5. Within this context and the specific affinity of the two proteins AtPAO1 and AtPAO5 to Spm (Nor and especially T-Spm) [52,81], we stress the specific implication of Spm oxidation in HS response. AtPAO3 is also highly affected by the deletion of the HSP90 action but seems to follow different pattern. Furthermore, the transcriptional analysis of the four cytosolic AtHSP90 genes in the Atpao3 mutant reveals the high endogenous AtHSP90 transcript levels in this mutant and once again the putative mutual inhibitory effect.

Overall, our results suggest a link between HSP90s and PAs/PAOs/ $\mathrm{H}_{2} \mathrm{O}_{2}$ under HS. As schematically presented in the proposed model (Figure 7), HSP90 proteins participate in the regulation of PA conjugation, more specifically, in PA acetylation. The pLFY:HSP90RNAi plants exhibit: (i) overexpression of the major AtPAO genes and consequently increased PAO protein and activity levels, which result in increased $\mathrm{H}_{2} \mathrm{O}_{2}$ intrinsic levels; and (ii) significant increase of PAs and, especially, of acetylated higher PAs titers. In turn, underexpression of the AtPAO3 gene (Atpao3 mutant), induces overexpression of one or more of the AtHSP90 1-4 genes. Under conditions of HS as pivotal HSP90 stimulator: (1) the transgenic reduction of the HSP90 genes ( 2 LFY:HSP90RNAi), as well as the pharmacological inhibition of the HSP90 proteins via Rad affect similarly both pathways. Namely: (i) positive regulation of the AtPAOs and further increase of the PAOs-generated $\mathrm{H}_{2} \mathrm{O}_{2}$, which is also observed under HS conditions in the WT, but to a lesser extent, suggesting that HSP90s are involved in the regulation of the stress-induced PA-oxidation/back-conversion pathway; and, (ii) increase of PAs and acetylated-higher PAs, showing a specific heat-related HSP90 pathway as revealed by HSP90 inhibition. Consequently, by being powerful modulators of PAOs, HSP90s affect the PAO-generated $\mathrm{H}_{2} \mathrm{O}_{2}$, which participates in the stress-induced downstream signaling cascade that is tidily related to ROS homeostasis and PCD [38,43,50,51,61,82,83].

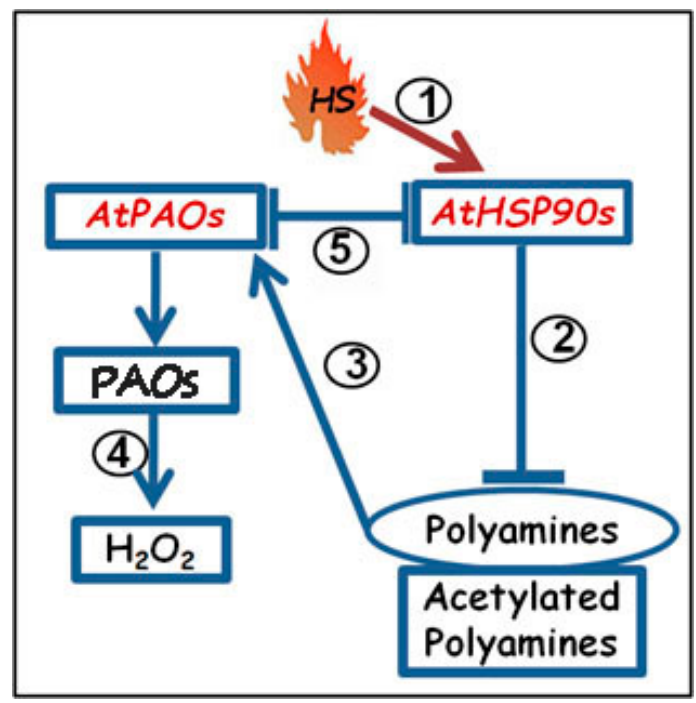

Figure 7. Proposed model of Heat Shock Protein90s (HSP90s)/Polyamine oxidases (PAOs)/Polyamines (PAs) $/ \mathrm{H}_{2} \mathrm{O}_{2}$ cross-talk in Arabidopsis thaliana: Under conditions of HS, as pivotal HSP stimulator (1), the transgenic/pharmacological reduction of HSP90 genes/HS proteins stimulate an increase of PA and acetylated-PA levels (2), a positive regulation of AtPAOs (3), and further increase of the PAO-related $\mathrm{H}_{2} \mathrm{O}_{2}$ (4). Reciprocally, underexpression of AtPAO in Atpao3 mutant reveals stimulation of AtHSP90 transcripts and HSP90 protein levels (5). 
Taken all together, these results reveal a mutually antagonistic HS-regulated effect involving HSP90s, PAs, PAOs and $\mathrm{H}_{2} \mathrm{O}_{2}$ in Arabidopsis thaliana.

\section{Materials and Methods}

\subsection{Plant Material and Treatments}

Arabidopsis thaliana (ecotype Col-0, WT), an PLFY:HSP90RNAi silencing line against the four cytosolic AtHSP90 genes [22], two T-DNA insertion mutant lines for the Athsp90-1 and Athsp90-4 (SALK_007614 and SALK_084059, respectively) and a T-DNA loss-of-function Atpao3 (SALK_121288) line were used. In vitro produced seedlings were germinated on $\frac{1}{2}$ MS medium [84] supplemented with $0.5 \%$ sucrose on Petri dishes and plants were cultured in pots in a controlled growth chamber $\left(23^{\circ} \mathrm{C}\right.$ and $8 / 16 \mathrm{~h}$ photoperiod under $\left.150 \mu \mathrm{mol} \mathrm{m}^{-2} \mathrm{~s}^{-1}\right)$. Fully expanded leaves were excised from 4-week-old vegetative plants, before the floral transition phase, incubated in MES medium ( $\mathrm{pH}$ 5.7) with agitation for $24 \mathrm{~h}$, and subjected to different treatments: controls were incubated at $23^{\circ} \mathrm{C}$ and HS samples at $42{ }^{\circ} \mathrm{C}$, in the presence or absence of $10 \mathrm{mM} \mathrm{Spd}, 50 \mu \mathrm{M}$ guazatine (specific inhibitor of PAO), $300 \mathrm{nM}$ radicicol (specific inhibitor of HSP90) or $10 \mathrm{mM} \mathrm{H}_{2} \mathrm{O}_{2}$. Each chemical was added to the medium accompanied by brief vacuum treatment, $10 \mathrm{~min}$ prior to HS. All experiments were performed twice in identical growth chambers and growth conditions, with 4 replicates per treatment randomly designed. Samples were collected after $1 \mathrm{~h}$ treatment. Eight replicates from two independent experiments were pooled for statistical analysis. Asterisks indicate statistically significant differences from the WT control $(p<0.05)$.

\subsection{Construction of HSP90-RNAi Line (pLFY:HSP90RNAi Mutant)}

The construction of the HSP90-RNAi line is described in [22]. In this work, we analyzed the pLFY:HSP90RNAi mutant, line 10.1

\subsection{RNA Extraction, RT-PCR and Semi-Q RT-PCR Analysis}

Total RNA was extracted using the TRIZOL method (modified from Chomczinsky and Sacchi, [85]), any DNA contamination was removed with RQ1 RNase free DNase (Promega, Madison, WI, USA). About $1 \mu \mathrm{g}$ was used as template in first-strand cDNA synthesis using PrimeScriptTM 1st Strand cDNA Synthesis Kit (TaKaRa, Kusatsu, Shiga, Japan), according to the manufacturer's instructions. RT-PCR Transcript analysis was performed using the gene specific primers, sequences relative sizes for RT-PCR are: AtPAO1: 468 bp, AtPAO3: 624 bp, AtPAO5: 269 bp, AtHSP90-1: 725 bp, AtHSP90-2: 197 bp, AtHSP90-3: 352 bp and AtHSP90-4: 234 bp (Table S1).

For the semi-Q RT-PCR, 5, 10 and 15 day-old seedlings of Arabidopsis wild type (Col) and Atpao3 were used. First strand cDNA was synthesized using total RNA from each plant sample using SuperScript II Reverse Transcriptase (Invitrogen) in a $20 \mu \mathrm{L}$ reaction. PCR amplification for each transcript (AtHSP90-1: $392 \mathrm{bp}$, AtHSP90-2: $192 \mathrm{bp}$, AtHSP90-3: $2531 \mathrm{bp}$ and the AtHSP90-4: $128 \mathrm{bp}$ ) was performed using the gene-specific primers (Table S1). RT-PCR and semi-Q RT-PCR reactions were normalized using the $U b q$ and $18 S$ DDNA Arabidopsis genes, respectively [86]. For all semi-Q RT-PCRs, three technical replicates were prepared from materials pooled from all biological replicates/experiments. At least three variations in cycle number were used to verify reproducibility and amplification in the logarithmic phase, respectively. To estimate the amount of PCR product obtained, PCR reactions were run on ethidium bromide-containing agarose gels and subsequently analyzed in UV light. During gel analysis and data collection, volumes and settings were chosen to avoid saturation of fluorescence signals. RT and semi-Q RT-PCR products were quantified by measuring the intensity per unit area with Image J. The gene specificity of RT-PCR products was confirmed by sequencing. Data represent the mean of the technical replicates. 


\subsection{Determination and In Situ Localization of Hydrogen Peroxide}

Hydrogen peroxide was quantified via a chemiluminescence assay [87]. In situ $\mathrm{H}_{2} \mathrm{O}_{2}$ was detected by DAB staining using the method of Thordal et al. [88].

\subsection{Extraction and Quantification of PAs}

Polyamines were extracted and analyzed according to Kotzabasis et al. [89], using an HP 1100 high performance liquid chromatographer (HPLC; Hewlett-Packard, Wadbronn, Germany).

\subsection{Protein Extraction and Enzyme Assays}

Total proteins were extracted as described in Papadakis and Roubelakis-Angelakis [90]. Protein content was measured according to the Lowry method [91]. PAO activity was measured according to the method of Yoda et al. [43] with minor modifications; fifty $\mu \mathrm{g}$ protein extract were incubated with $10 \mathrm{mM} \mathrm{Spd}$ for $30 \mathrm{~min}$ and measurement of generated $\mathrm{H}_{2} \mathrm{O}_{2}$ was performed for $1 \mathrm{~min}$ using a luminometer in a Tris- $\mathrm{HCl}(\mathrm{pH}$ 8.0) reaction buffer containing $125 \mathrm{mM}$ luminol [92].

\subsection{Western Blotting}

Protein extracts were prepared with Laemmli buffer and $50 \mu \mathrm{g}$ of denaturated protein aliquots were loaded on $10 \%(v / v)$ polyacrylamide gel and electroblotted onto nitrocellulose membrane. Target proteins were then immunodetected against specific antibodies: a rabbit polyclonal anti-AtPAO3 anti-serum at a 1:10,000 dilution [39] and a monoclonal mouse anti-HSP90 at a 1:2000 dilution (Anti-HSP90 Mouse mAb, AC88, Calbiochem). For anti-AtPAO3 and anti-AtHSP90 horseradish peroxidase-conjugated anti-rabbit IgG (1:5,000) (Sigma, St Louis, MI, USA), or anti mouse IgG $(1: 10,000)$ (Sigma, St Louis, MI, USA) were used respectively. Western blots were developed using the Amersham ECL Prime Western Blotting Detection Reagent Kit (Pittsburg, CA, USA).

\subsection{Image and Statistical Analysis}

Image analysis was performed using ImageJ v 1.41 software, and statistical analysis using one-way ANOVA and the Duncan's test in the STATISTICA software.

Supplementary Materials: The following are available online at http://www.mdpi.com/2223-7747/8/9/323/s1, Figure S1: Soluble hydrolyzed (SH) PA fractions in leaves of 35 day-old WT and athsp90-1, athsp90-4 and pLFY;HSP90RNAi plants, Figure S2: Western blot, Figure S3: Inhibition of PAO leaves cultured in MES, treated with HS, in the presence/absence of guazatine (Guaz) as a specific inhibitor induces, Figure S4: Abudance of mRNA of AtHSP90-1, AtHSP90-2, AtHSP90-3, AtHSP90-4 genes in 5, 10 and 15 day-old WT and Atpao3 mutant seedings, Figure S5: Abundance of mRNA, Table S1: List of specific primers for RT-PCR.

Author Contributions: Conceptualization, I.T. and K.A.R.-A.; data curation, I.T., M.G.P., T.M. and D.M.; formal analysis, I.T. and K.A.R.-A.; funding acquisition, K.A.R.-A.; investigation, I.T. and K.A.R.-A.; methodology, I.T., M.G.P. and K.A.R.-A.; project administration, K.A.R.-A.; resources, I.T., T.M. and K.A.R.-A.; supervision, D.M. and K.A.R.-A.; validation, K.A.R.-A.; writing一original draft, I.T.; writing一review \& editing, D.M. and K.A.R.-A.

Funding: This work was funded by the EU and the Greek National funds, Research Funding Program THALES (MIS 377281 to K.A.R.-A.) and implemented in the frame of the EU COST FA1106 Action.

Conflicts of Interest: The authors declare no conflict of interest.

\section{References}

1. Song, H.; Zhao, R.; Fan, P.; Wang, X.; Chen, X.; Li, Y. Overexpression of AtHsp90.2, AtHsp90.5 and AtHsp90.7 in Arabidopsis thaliana enhances plant sensitivity to salt and drought stresses. Planta 2009, 229, 955-964. [CrossRef] [PubMed]

2. Lindquist, S.; Craig, E.A. The heat-shock proteins. Annu. Rev. Inc. 1988, 22, 631-677. [CrossRef] [PubMed]

3. De Maio, A.; Santoro, M.G.; Tanguay, R.M.; Hightower, L.E. Ferruccio Ritossa's scientific legacy 50 years after his discovery of the heat shock response: A new view of biology, a new society, and a new journal. Cell Stress Chaperones. 2012, 17, 139-143. [CrossRef] [PubMed] 
4. Zhang, J.; Srivastava, V.; Stewart, J.M.D. Molecular biology and physiology: Heat-tolerance in cotton is correlated with induced overexpression of heat-shock factors, heat-shock proteins, and general stress response genes. J. Cotton Sci. 2016, 20, 253-262.

5. Queitsch, C.; Sangster, T.A.; Lindquist, S. Hsp90 as a capacitor of phenotypic variation. Nature 2002, 417, 618-624. [CrossRef] [PubMed]

6. Song, H.; Fan, P.; Shi, W.; Zhao, R.; Li, Y. Expression of five AtHsp90 genes in Saccharomyces cerevisiae reveals functional differences of AtHsp90s under abiotic stresses. J. Plant Physiol. 2010, 167, 1172-1178. [CrossRef]

7. Hahn, A.; Bublak, D.; Schleiff, E.; Scharf, K.D. Crosstalk between Hsp90 and Hsp70 chaperones and stress treanscription factors in tomato. Plant Cell 2011, 23, 741-755. [CrossRef] [PubMed]

8. Bernfur, K.; Rutsdottir, G.; Emanuelsson, C. The chloroplast-localized small heat shock protein Hsp21 associates with the thylakoid membranes in heat-stressed plants. Protein Sci. 2017, 26, 1773-1784. [CrossRef]

9. Kriechbaumer, V.; von Löffelholz, O.; Abell, B.M. Chaperone receptors: Guiding proteins to intracellular compartments. Protoplasma 2012, 249, 21-30. [CrossRef]

10. Wang, R.; Zhang, Y.; Kieffet, M.; Yu, H.; Kepinski, S.; Estelle, M. HSP90 regulates temperature-dependent seedling growth by stabilizing the auxin co-receptor F-box protein TIR1. Nat. Commun. 2016, 7, 10269. [CrossRef]

11. Crookes, W.J.; Olsen, L.J. The effects of chaperones and the influence of protein assembly on peroxisomal protein import. J. Biol. Chem. 1998, 273, 17236-17242. [CrossRef] [PubMed]

12. Milioni, D.; Hatzopoulos, P. Genomic organization of HSP90 gene family in Arabidopsis. Plant Mol. Biol. 1997, 35, 955-961. [CrossRef] [PubMed]

13. Haralampidis, K.; Milioni, D.; Rigas, S.; Hatzopoulos, P. Combinatorial interaction of cis elements specifies the expression of the Arabidopsis AtHsp90-1 gene. Plant Physiol. 2002, 129, 1138-1149. [CrossRef] [PubMed]

14. Prasinos, C.; Krampis, K.; Samakovli, D.; Hatzopoulos, P. Tight regulation of expression of two Arabidopsis cytosolic HSP90 genes during embryo development. J. Exp. Bot. 2004, 56, 633-644. [CrossRef] [PubMed]

15. Sangster, T.A.; Bahrami, A.; Wilczek, A.; Watanabe, E.; Schellenberg, K. Phenotypic diversity and altered environmental plasticity in Arabidopsis thaliana with reduced Hsp90 levels. PLoS ONE 2007, 2, e684. [CrossRef]

16. Prassinos, C.; Haralampidis, K.; Milioni, D.; Samakovli, D.; Krambis, K.; Hatzopoulos, P. Complexity of Hsp90 in organelle targeting. Plant Mol. Biol. 2008, 67, 323-334. [CrossRef]

17. Krishna, P.; Gloor, G. The Hsp90 family of proteins in Arabidopsis thaliana. Cell Stress Chaperones 2001, 6, 238-246. [CrossRef]

18. Yamada, K.; Nishimura, M. Cytosolic heat shock protein 90 regulates heat shock transcription factor in Arabidopsis thaliana. Plant Signal. Behav. 2008, 3, 660-662. [CrossRef]

19. Xu, Z.S.; Li, Z.Y.; Chen, Y.; Chen, M.; Li, L.C.; Ma, Y.Z. Heat shock protein 90 in plants: Molecular mechanisms and roles in stress responses. Int. J. Mol. Sci. 2012, 13, 15706-15723. [CrossRef]

20. Samakovli, S.; Thanou, A.; Valmas, C.; Hatzopoulos, P. Hsp90 canalizes developmental perturbation. J. Exp. Bot. 2007, 58, 3513-3524. [CrossRef]

21. Kotak, S.; Vierling, E.; Baumlein, H.; von Koskull-Doring, P. A novel transcriptional cascade regulating expression of heat stress proteins during seed development of Arabidopsis. Plant Cell 2007, 19, 182-195. [CrossRef] [PubMed]

22. Margaritopoulou, T.; Kryovrysanaki, N.; Megkoula, P.; Prasinos, C.; Samakovli, D.; Milioni, D.; Hatzopoulos, P. HSP90 canonical content organizes a molecular scaffold mechanism to progress flowering. Plant J. 2016, 87, 174-187. [CrossRef] [PubMed]

23. Bao, F.; Huang, X.; Zhu, C.; Zhang, X.; Li, X.; Yang, S. Arabidopsis HSP90 protein modulates RPP4-mediated temperature-dependent cell death and defense responses. New Phytol. 2014, 202, 1320-1334. [CrossRef] [PubMed]

24. Shigeta, T.; Zaizen, Y.; Asami, T.; Yoshida, S.; Nakamura, Y.; Okamoto, S.; Matsuo, T.; Sugimoto, Y. Molecular evidence of the involvement of heat shock protein 90 in brassinosteroid signaling in Arabidopsis T87 cultured cells. Plant Cell Rep. 2014, 33, 499-510. [CrossRef] [PubMed]

25. Samakovli, D.; Margaritopoulou, T.; Prassinos, C.; Milioni, D.; Hatzopoulos, P. Brassinosteroid nuclear signaling recruits HSP90 activity. New Phytol. 2014, 203, 743-757. [CrossRef] [PubMed]

26. Samakovli, D.; Ticha, T.; Ovecka, M.; Luptovciak, I.; Zapletalova, V.; Krasylenko, Y.; Komis, G.; Samajova, O.; Margaritopoulou, T.; Roka, L.; et al. Environment and HSP90 modulate MAPK stomatal developmental pathway. BioRxiv 2018, 426684. [CrossRef] 
27. Inoue, H.; Li, M.; Schnell, D.J. An essential role for chloroplast heat shock protein 90 (Hsp90C) in protein import into chloroplasts. PNAS 2013, 110, 3173-3178. [CrossRef] [PubMed]

28. Kindgren, P.; Noren, L.; de Dios, J.; Lopez, B.; Shaikhali, J.; Strand, A. Interplay between Heat Shock Protein 90 and HY5 controls PhANG expression in response to the GUN5 plastid signal. Mol. Plant 2012, 5, 901-913. [CrossRef] [PubMed]

29. Kadota, Y.; Shirasu, K.; Guerios, R. NLR sensors meet at the SGT1-HSP90 crossroad. Trends Biochem. Sci. 2010, 35, 199-207. [CrossRef]

30. Miernyk, J.A. Protein folding in the Plant Cell. Plant Physiol. 1999, 121, 695-703. [CrossRef]

31. Hong, S.W.; Vierling, E. Mutants of Arabidopsis thaliana defective in the acquisition of tolerance to high temperature stress. PNAS 2000, 97, 4392-4397. [CrossRef] [PubMed]

32. Wang, W.; Vinocur, B.; Shoseyov, O.; Altman, A. Role of plant heat-shock proteins and molecular chaperones in the abiotic stress response. Trends Plant Sci. 2004, 9, 244-252. [CrossRef] [PubMed]

33. Kozeko, L.Y. The role of HSP90 chaperones in stability and plasticity of ontogenesis of plants under normal and stressful conditions (Arabidopsis thaliana). Cytol. Genet. 2019, 2019. 53, 143-161. [CrossRef]

34. Clark, C.B.; Rane, M.J.; El Mehdi, D.; Miller, C.J.; Sachleben, L.R., Jr.; Gozal, E. Role of oxidative stress in geldanamycin-induced cytotoxicity and disruption of Hsp90 signaling complex. Free Radic. Biol. Med. 2009, 47, 1440-1449. [CrossRef] [PubMed]

35. Tiburcio, A.F.; Altabella, T.; Bitrián, M.; Alcázar, R. The roles of Polyamines during the lifespan of plants: from development to stress. Planta 2014, 240, 1-18. [CrossRef] [PubMed]

36. Bagni, N.; Tassoni, A. Biosynthesis, oxidation and conjugation of aliphatic Polyamines in higher plants. $J$ Amino Acids 2001, 20, 301-317. [CrossRef]

37. Moschou, P.N.; Delis, I.D.; Paschalidis, K.A.; Roubelakis-Angelakis, K.A. Transgenic tobacco plants overexpressing poliamine oxidase are not able to cope with oxidative burst generated by abiotic factors. Physiol. Plant 2008, 133, 140-156. [CrossRef]

38. Moschou, P.N.; Paschalidis, K.A.; Delis, I.D.; Andriopoulou, A.H.; Lagiotis, G.D.; Yakoumakis, D.I.; Roubelakis-Angelakis, K.A. Spermidine exodus and oxidation in the apoplast induced by abiotic stress is responsible for $\mathrm{H}_{2} \mathrm{O}_{2}$ signatures that direct tolerance responses in tobacco. Plant Cell 2008, 20, 1708-1724. [CrossRef]

39. Moschou, P.N.; Sanmartin, M.; Andriopoulou, A.H.; Rojo, E.; Sanchez-Serrano, J.J.; Roubelakis-Angelakis, K.A. Bridging the gap between plant and mammalian polyamine catabolism: A novel peroxisomal polyamine oxidase responsible for a full back-conversion pathway in Arabidopsis. Plant Physiol. 2008, 147, 1845-1857. [CrossRef]

40. Paschalidis, K.A.; Roubelakis-Angelakis, K.A. Spatial and temporal distribution of polyamine levels and polyamine anabolism in different organs/tissues of the tobacco plant: Correlations with Age, Cell Division/Expansion, and Differentiation. Plant Physiol. 2005, 138, 142-152. [CrossRef]

41. Paschalidis, K.A.; Roubelakis-Angelakis, K.A. Sites and regulation of polyamine catabolism in the tobacco plant. Correlations with cell division/expansion, cell-cycle progression, and vascular development. Plant Physiol. 2005, 138, 2174-2184. [CrossRef] [PubMed]

42. Mattoo, A.K.; Minocha, S.C.; Minocha, R.; Handa, A.K. Polyamines and cellular metabolism in plants: Transgenic approaches reveal different responses to diamine putrescine versus higher Polyamines spermidine and spermine. Amino Acids 2010, 38, 405-413. [CrossRef] [PubMed]

43. Yoda, H.; Yamaguchi, Y.; Sano, H. Induction of hypersensitive cell death by Hydrogen Peroxide produced through polyamine degradation in tobacco plants. Plant Physiol. 2003, 132, 1973-1981. [CrossRef] [PubMed]

44. Yamaguchi, K.; Takahashi, Y.; Berberich, T.; Imai, A.; Takahashi, T.; Michael, A.J.; Kusano, T. A Protective role for the polyamine spermine against drought stress in Arabidopsis. Biochem. Biophys. Res. Commun. 2007, 352, 486-490. [CrossRef] [PubMed]

45. Fincato, P.; Moschou, P.N.; Spedaletti, V.; Tavazza, R.; Angelini, R.; Federico, R.; Roubelakis-Angelakis, K.A.; Tavladoraki, P. Functional diversity inside the Arabidopsis polyamine oxidase gene family. J. Exp. Bot. 2011, 62, 1155-1168. [CrossRef] [PubMed]

46. Fincato, P.; Moschou, P.N.; Ahou, A.; Angelini, R.; Roubelakis-Angelakis, K.A.; Federico, R.; Tavladoraki, P. The members of Arabidopsis thaliana PAO gene family exhibit distinct tissue- and organ-specific expression pattern during seedling growth and flower development. Amino Acids 2012, 42, 831-841. [CrossRef] [PubMed] 
47. Tisi, A.; Federico, R.; Moreno, S.; Lucretti, S.; Moschou, P.N.; Roubelakis-Angelakis, K.A.; Angelini, R.; Cona, A. Perturbation of polyamine catabolism can strongly affect root development and xylem differentiation. Plant Physiol. 2011, 157, 200-215. [CrossRef]

48. Kudou, M.; Shiraki, K.; Fujiwara, S.; Imanaka, T.; Takagi, M. Prevention of thermal inactivation and aggregation of lysozymes by Polyamines. Eur. J. Biochem. 2003, 270, 4547-4554. [CrossRef]

49. Königshofer, H.; Lechner, S. Are Polyamines involved in the synthesis of heat-shock proteins in cell suspension cultures of tobacco and alfalfa in response to high-temperatture stress? Plant Physiol. Biochem. 2002, 40, 51-59. [CrossRef]

50. Moschou, P.N.; Roubelakis-Angelakis, K.A. Polyamines and programmed cell death. J. Exp. Bot. 2013, 65, 1285-1296. [CrossRef]

51. Tavladoraki, P.; Cona, A.; Federico, R.; Tempera, G.; Viceconte, N.; Saccocio, S.; Battaglia, V.; Toninello, A.; Agostinelli, E. Polyamine catabolism: Target for antiproliferative therapies in animals and stress tolerance strategies in plants. Amino Acids 2012, 42, 411-426. [CrossRef] [PubMed]

52. Yoda, H.; Fujimura, K.; Takahashi, H.; Munemura, I.; Uchimiya, H.; Sano, H. Polyamines as a common source of hydrogen peroxide in host- and nonhost hypersensitive response during pathogen infection. Plant Mol. Biol. 2009, 70, 103-112. [CrossRef] [PubMed]

53. Tavladoraki, P.; Rossi, M.N.; Saccuti, G.; Perez-Amador, M.A.; Polticelli, F.; Angelini, R.; Federico, R. Heterologous expression and biochemical characterization of a polyamine oxidase from Arabidopsis involved in polyamine back conversion. Plant Physiol. 2006, 141, 1519-1532. [CrossRef] [PubMed]

54. Kamada-Nobusada, T.; Makoto, H.; Fukazawa, M.; Sakakibara, H.; Nishimura, M. A putative peroxisomal polyamine oxidase, AtPAO4, is involved in polyamine catabolism in Arabidopsis thatiana. Plant Cell Physiol. 2008, 49, 1272-1282. [CrossRef] [PubMed]

55. Angelini, R.; Cona, A.; Federico, R.; Fincato, P.; Tavladoraki, P.; Tisi, A. Plant amine oxidases "on the move": An update. Plant Physiol. Biochem. 2010, 48, 560-564. [CrossRef] [PubMed]

56. Moschou, P.N.; Roubelakis-Angelakis, K.A. Characterization, assay, and substrate specificity of plant polyamine oxidases. Meth. Mol. Biol. 2001, 720, 183-194.

57. Pantano, C.; Shrivastava, P.; McElhinney, B.; Janssen-Heininger, Y. Hydrogen peroxide signaling through tumor necrosis factors receptor 1 leads to selective activation of c-Jun N-terminal kinase. J. Biol. Chem. 2003, 278, 44091-44096. [CrossRef]

58. Baxter, A.; Mittler, R.; Suzuki, N. ROS as key players in plant stress signalling. J. Exp. Bot. 2004, 65, 1229-1240. [CrossRef]

59. Ghuge, S.A.; Tisi, A.; Carucci, A.; Rodrigues-Pousada, R.A.; Franchi, S.; Tavladoraki, P.; Angelini, R.; Cona, A. Cell wall amine oxidases: New players in root xylem differentiation under stress conditions. Plants 2015, 4, 489-504. [CrossRef]

60. Wang, W.; Paschalidis, K.; Feng, J.C.; Song, J.; Liu, J.H. Polyamine catabolism in plants: A universal process with diverse functions. Front. Plant Sci. 2019, 10. [CrossRef]

61. Gémes, K.; Kim, Y.J.; Park, K.Y.; Moschou, P.N.; Andronis, E.; Valassakis, C.; Roussis, A.; Roubelakis-Angelakis, K.A. A NADPH-Oxidase/polyamine oxidase feedback loop controls oxidative burst under salinity. Plant Physiol. 2016, 172, 1418-1431. [CrossRef] [PubMed]

62. Casero, R.A., Jr.; Pegg, A.E. Spermidine/spermine N1-acetyltransferase-The turning point in polyamine metabolism. FASEB J. 1991, 7, 653-661.

63. Bardocz, S.; White, A. Effect of lectins on uptake of Polyamines. Meth. Mol. Med. 1998, 9, $393-405$.

64. Desiderio, M.A.; Dansi, P.; Tacchini, L.; Bernelli-Zazzera, A. Influence of Polyamines on DNA binding of heat shock and activator protein 1 transcription factors induced by heat shock. FEBS Lett. 1999, 455, 149-153. [CrossRef]

65. Sagor, G.H.; Berberich, T.; Takahashi, Y.; Niitsu, M.; Kusano, T. The polyamine spermine protects Arabidopsis from heat stress-induced damage by increasing expression of heat shock-related genes. Transgenic Res. 2013, 22, 595-605. [CrossRef] [PubMed]

66. Mellidou, I.; Karamanoli, K.; Berris, D.; Haralampidis, K.; Constantinidou, H.I.; Roubelakis-Angelakis, K.A. Underexpression of apoplastic polyamine oxidase improves thermotolerance in Nicotiana tabacum. J. Plant Physiol. 2017, 218, 171-174. [CrossRef] [PubMed] 
67. Adio, A.M.; Casteel, C.L.; de Vos, M.; Kim, J.H.; Joshi, V.; Li, B.; Juéry, C.; Daron, J.; Kliebenstein, D.J.; Jander, G. Biosynthesis and defensive function of $\mathrm{N} \delta$-acetylornithine, a jasmonate-induced Arabidopsis metabolite. Plant Cell 2011, 23, 3303-3318. [CrossRef] [PubMed]

68. Lou, Y.R.; Bor, M.; Yan, J.; Preuss, A.S.; Jander, G. Arabidopsis NATA1 acetylates Putrescine and decreases defense-related hydrogen peroxide accumulation. Plant Physiol. 2016, 171, 1443-1455. [CrossRef] [PubMed]

69. Tassoni, A.; van Buuren, M.; Franceschetti, M.; Fornalè, S.; Bagni, N. Polyamine content and metabolism in Arabidopsis thaliana and effect of spermidine on plant development. Plant Physiol. Biochem. 2000, 38, 383-393. [CrossRef]

70. Kee, K.; Foster, B.A.; Merali, S.; Kramer, D.L.; Hensen, M.L.; Diegelman, P.; Kisiel, N.; Vujcic, S.; Mazurchuk, R.V.; Porter, C.W. Activated polyamine catabolism depletes acetyl-CoA pools and suppresses prostate tumor growth in TRAMP mice. J. Biol. Chem. 2004, 279, 40076-40083. [CrossRef] [PubMed]

71. Pegg, A.E. Spermidine/Spermine-N ${ }^{1}$-acetyltransferase: A key metabolic regulator. Am. J. Physiol. Endocrinol. Metab. 2008, 294, 995-1010. [CrossRef] [PubMed]

72. Tian, Y.; Wang, S.; Wang, B.; Zhang, J.; Jiang, R.; Zhang, W. Overexpression of SSAT by DENSPM treatment induces cell detachment and apoptosis in glioblastoma. Oncol. Rep. 2012, 27, 1227-1232. [CrossRef] [PubMed]

73. Fliniaux, O.; Mesnard, F.; Raynaud-Le Grandic, S.; Baltora-Rosset, S.; Bienaimé, C.; Robins, R.J.; Fliniaux, M.A. Altered nitrogen metabolism associated with de-differentiated suspension cultures derived from root cultures of Datura stramonium studied by heteronuclear multiple bond coherence (HMBC) NMR spectroscopy. J. Exp. Bot. 2004, 55, 1053-1060. [CrossRef] [PubMed]

74. Alcázar, R.; Planas, J.; Saxena, T.; Zarza, X.; Bortolotti, C.; Cuevas, J.; Bitrián, M.; Tiburcio, A.F.; Altabella, T. Putrescine accumulation confers drought tolerance in transgenic Arabidopsis plants over-expressing the homologous Arginine decarboxylase 2 gene. Plant Physiol. Biochem. 2010, 48, 547-552. [CrossRef] [PubMed]

75. Chen, F.; Pandey, D.; Chadi, A.; Catravas, J.D.; Chen, T.; Fulton, D.J. Hsp90 regulates NADPH oxidase activity and its necessary for superoxide but not hydrogen peroxide production. Antioxid. Redox. Signal 2011, 14, 2107-2119. [CrossRef] [PubMed]

76. Xu, X.; Song, H.; Zhou, Z.; Shi, N.; Ying, Q.; Wang, H. Functional characterization of AtHsp90.3 in Saccharomyces cerevisiae and Arabidopsis thaliana under heat stress. Biotechnol Lett. 2010, 32, 979-987. [CrossRef] [PubMed]

77. Wiech, H.; Buchner, J.; Zimmermann, R.; Jakob, U. Hsp90 chaperones protein folding in vitro. Nature 1992, 358, 169-170. [CrossRef]

78. Wang, C.; Gu, X.; Wang, X.; Guo, H.; Geng, J.; Yu, H.; Sun, J. Stress response and potential biomarkers in spinach (Spinacia oleracea L.) seedlings exposed to soil lead. Ecotoxicol. Environ. Saf. 2011, 74, 41-47. [CrossRef]

79. Nishizawa-Yokoi, A.; Tainaka, H.; Yoshida, E.; Tamoi, M.; Yabuta, Y.; Shigeoka, S. The 26S Proteasome Function and Hsp90 activity involved in the regulation of HsfA2 expression in response to oxidative stress. Plant Cell Physiol. 2010, 51, 486-496. [CrossRef]

80. McLellan, C.A.; Turbyvilee, T.J.; Wijeratne, E.K.; Kerschen, A.; Vierling, E.; Queitsch, C.; Whitesell, L.; Gunatilaka, A.L. A Rhizosphere fungus enhances Arabidopsis thermotolerance through production of an HSP90 inhibitor. Plant Physiol. 2007, 145, 174-182. [CrossRef]

81. Kim, D.W.; Watanabe, K.; Murayama, C.; Izawa, S.; Niitsu, M.; Michael, A.J.; Berberich, T.; Kusano, T. Polyamine oxidase 5 regulates Arabidopsis growth through Thermospermine Oxidase activity. Plant Physiol. 2014, 165, 1575-1590. [CrossRef] [PubMed]

82. Paschalidis, A.K.; Toumi, I.; Moschou, N.P.; Roubelakis-Angelakis, K.A. ABA-dependent amine oxidases-derived $\mathrm{H}_{2} \mathrm{O}_{2}$ affects stomata conductance. Plant Signal. Behav. 2010, 5, 1153-1156.

83. Andronis, E.A.; Moschou, P.N.; Toumi, I.; Roubelakis-Angelakis, K.A. Peroxisomal polyamine oxidase and NADPH-oxidase cross-talk for ROS homeostasis which affects respiration rate in Arabidopsis thaliana. Front. Plant Sci. 2014, 3, 132. [CrossRef] [PubMed]

84. Murashige, T.; Skoog, F. A revised medium for rapid growth and bioassays with tobacco tissue culture. Physiol. Plant. 1962, 15, 473-497. [CrossRef]

85. Chomczinsky, P.; Sacchi, N. Single-step method of RNA isolation by acid guanidinium thiocyanate-phenol-chloroform extraction. Anal. Biochem. 1987, 162, 156-159. [CrossRef] 
86. Galeano, E.; Vasconcelos, T.S.; Ramiro, D.A.; de Martin, V.d.F.; Carrer, H. Identification and validation of quantitative real-time reverse transcription PCR reference genes for gene expression analysis in Teak (Tectona grandis L.f.). BMC Res. Notes 2014, 7, 464. [CrossRef] [PubMed]

87. Papadakis, A.K.; Roubelakis-Angelakis, K.A. The regeneration of active oxygen species differs in tobacco and grapevine mesophyll protoplasts. Plant Physiol. 1999, 121, 197-206. [CrossRef]

88. Thordal-Christensen, H.; Zhang, Z.; Wei, Y.; Collinge, D.B. Subcellular localization of $\mathrm{H}_{2} \mathrm{O}_{2}$ in plants. $\mathrm{H}_{2} \mathrm{O}_{2}$ accumulation in papillae and hypersensitive response during the barley-powdery mildew interaction. Plant J. 1997, 11, 1187-1194. [CrossRef]

89. Kotzabasis, K.; Christakis-Hampsas, M.D.; Roubelakis-Angelakis, K.A. A narrow-bore HPLC method for the identification and quantitation of free, conjugated, and bound Polyamines. Analyt. Biochem. 1993, 214, 484-489. [CrossRef]

90. Papadakis, A.K.; Roubelakis-Angelakis, K.A. Polyamines inhibit NADPH oxidase-mediated superoxide generation and putrescine prevents programmed cell death induced by polyamine oxidase-generated hydrogen peroxide. Planta 2005, 220, 826-837. [CrossRef]

91. Lowry, O.H.; Rosebrough, N.J.; Farr, A.L.; Randall, R.J. Protein measurement with the Folin phenol reagent. J. Biol. Chem. 1951, 193, 265-275. [PubMed]

92. Bolwell, G.P.; Butt, V.S.; Davies, D.R.; Zimmerlin, A. The origin of the oxidative burst in plant cells. Free Radic. Res. 1995, 23, 517-532. [CrossRef] [PubMed]

(C) 2019 by the authors. Licensee MDPI, Basel, Switzerland. This article is an open access article distributed under the terms and conditions of the Creative Commons Attribution (CC BY) license (http://creativecommons.org/licenses/by/4.0/). 